\title{
Measuring Taylor Slough Boundary and Internal Flows, Everglades National Park, Florida
}

U.S. Geological Survey

Open-File Report 01-225

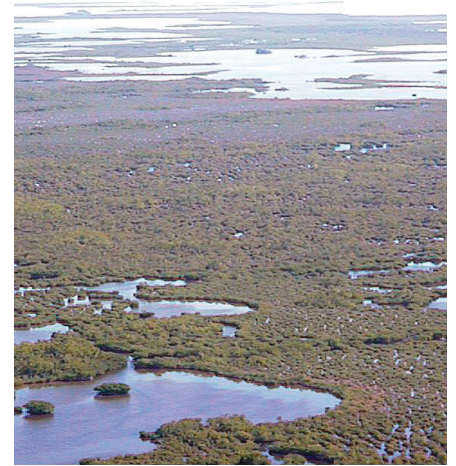

By Gina M. Tillis

\section{Abstract}

Four intensive data-collection efforts, intended to represent the spectrum of precipitation events and associated flow conditions, were conducted during 1997 and 1998 in the Taylor Slough Basin, Everglades National Park. Flow velocities were measured by newly developed, portable Acoustic Doppler Velocity meters along three transects bisecting the Taylor Slough Basin from east to west, roughly perpendicular to the centerline axis of the slough as well as a fourth transect along the slough's axis. These meters provided the required levels of accuracy in flow-velocity measurements while enabling the rapid collection of multiple time series of flow data at remote sites. Concurrently, flow measurements were made along bordering road culverts and under L-31W and Taylor Slough bridges. Flows across the study area's boundaries provided net flow of water into the system and transect measurements provided flow data within the basin. Collected data are available through the World Wide Web (http://sofia.usgs.gov/projects/flow_velocity/). The highwater and low-water events corresponded with the highest and lowest flow velocities, respectively. The July 1998 data had lower than expected flow velocities and, in some cases, strong winds reversed flow direction. 
American alligator

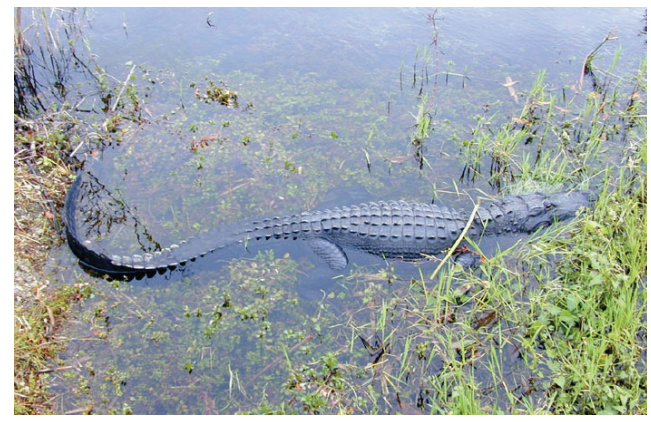

\section{INTRODUCTION}

Over the last century, man has extensively altered the hydrologic system of southern Florida by constructing a system of canals and levees for the purposes of draining the wetlands, providing water supply, and controlling floods. Although these efforts made southern Florida more suitable for urbanization and agriculture, they created another set of problems, which included lowering of ground- and surface-water levels caused by over-drainage, frequent dry-season fires in drought-stricken wetlands, and saltwater intrusion in coastal areas.

Taylor Slough (fig. 1), historically a major contributor of freshwater to Florida Bay, lies within the southeastern part of Everglades National Park (ENP). The duration, timing, and extent of wetland inundation of Taylor Slough's interconnected wetlands and freshwater flows through Florida Bay creeks are a critical component of the Everglades ecosystem. Since the mid-1960's, numerous control structures on the L-31W and C-111 canals have manipulated Taylor Slough water levels, resulting in altered timing and distribution of flows into Taylor Slough. Hydrologic regime alterations promoted hypersaline conditions in Florida Bay, altered plant and animal communities, decreased populations of wading bird and animal species, and reduced habitat. Anthropogenic encroachment has placed the Cape Sable seaside sparrow, American crocodile, and Florida panther on the endangered species list, and has had many other detrimental effects on the ecosystem. To better manage the system, inflow and circulation patterns for the Taylor Slough Basin are being analyzed so that the natural timing and distribution of flows to the basin can assist water-resource managers in the overall Everglades restoration effort (McPherson and others, 1999).

The U.S. Geological Survey (USGS), in cooperation with the Everglades National Park, began a study in 1997 to collect hydrologic data in the Taylor Slough Basin. The study was accomplished as part of the South Florida Ecosystem Program, a collaborative effort by the USGS, various other Federal, State, and local agencies and Indian tribes, to provide earth science information needed to resolve land-use and water issues in southern Florida. Ongoing efforts are underway by the USGS and ENP to collect additional hydrologic data in the park.

\section{Purpose and Scope}

The purpose of this report is to describe the methodology used in collecting and assimilating flow data in the Taylor Slough Basin and to reference the resultant data archive available on the World Wide Web (http://sofia.usgs.gov/projects/flow_velocity/). Data were collected at boundary and internal sites to help calibrate and verify a hydrodynamic model of the interconnected wetland and tidal ecosystem and to provide baseline data for evaluating processes such as evapotranspiration, flow resistance effects of vegetation, and ground-water/surface-water interactions. This effort was one of three concurrent studies collecting flow data across the study area's boundaries. Flow data through Florida Bay's tidal creeks and along the C-111 canal overbank and outflow areas are available at http://sofia.usgs.gov/projects/freshwtr_flow/\#data and http://sofia.usgs.gov/projects/coupling_mdls, respectively (Patino, undated; Schaffranek, undated). 
Figure 1. Location of Taylor Slough study area, south Florida.
This report describes data-collection methods, illustrates one of the available data formats, identifies geometric properties of the internal transects, and discusses seasonal variability in surface-flow velocity magnitude and direction through the Taylor Slough Basin. Data collection was conducted during four intensive collection efforts (July 1997, September 1997, November 1997, and July 1998) and covered a wide spectrum of precipitation events and associated flow conditions. Seasonal variability in surface flow within the basin as well as net flow of water into the system is documented.

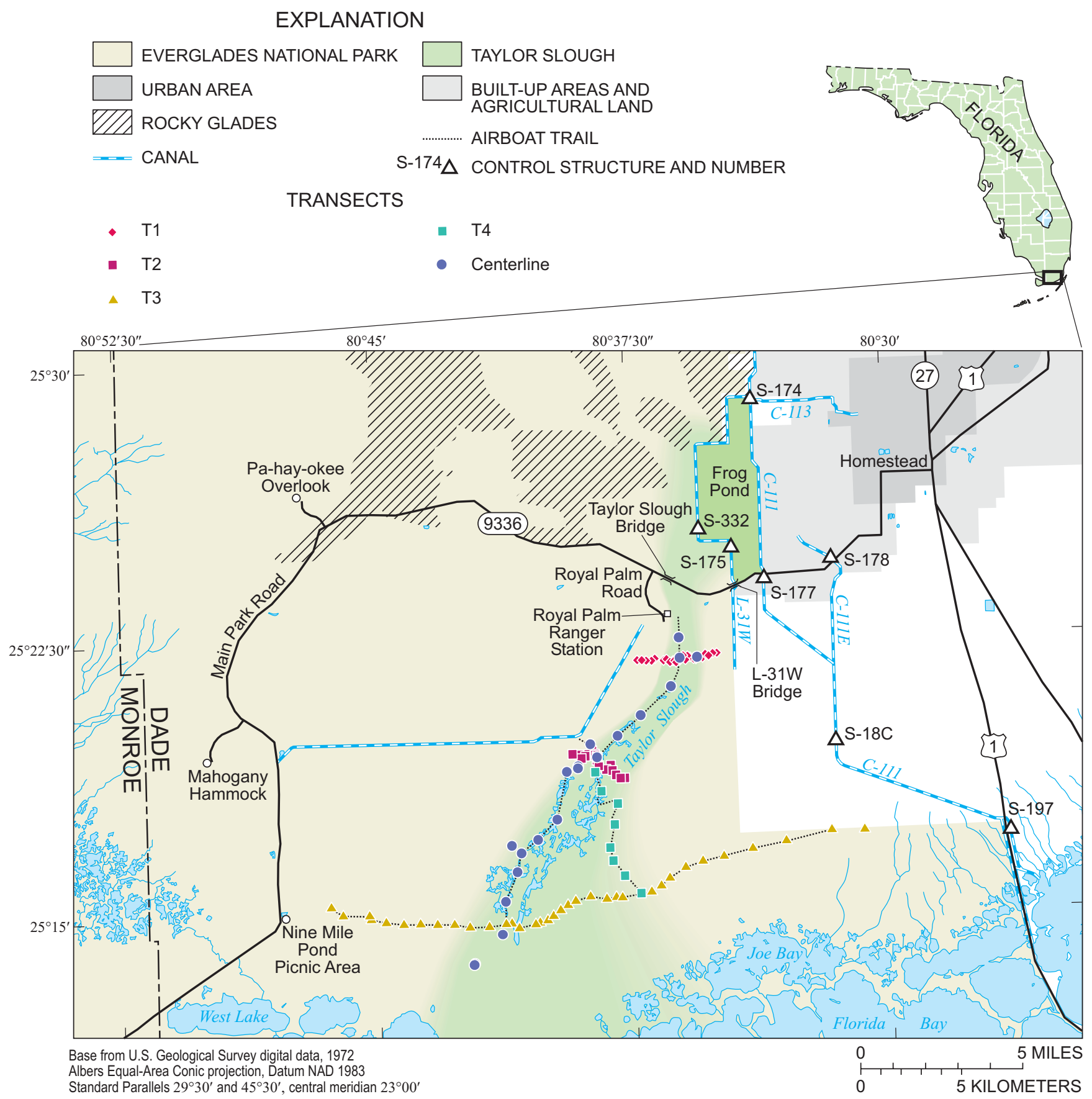


Figure 2. Aerial view of Taylor Slough.

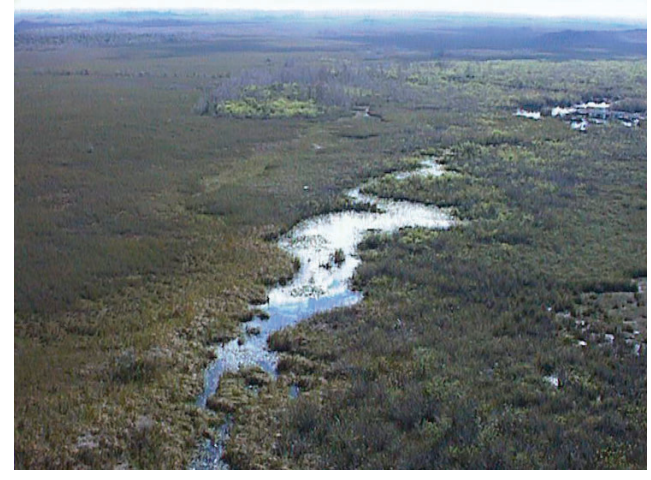

\section{Previous Studies}

The Everglades hydrologic cycle has intrigued researchers and environmentalists for decades. Among numerous studies in the Taylor Slough Basin, the following are examples that have analyzed the relation between rainfall, water levels, and outflows to Florida Bay (Meyer and Hull, 1969; Van Lent, 1993; Van Lent and others, 1993; Tsihrintzis and others, 1996; Bales and others, 1997). However, internal flows were difficult to quantify during the aforementioned studies as a result of instrumentation limitations and adverse environmental conditions.

\section{Area Description}

Taylor Slough, with headwaters in the Rocky Glades area of western Dade County, provides one of two major freshwater pathways into eastern Everglades National Park (fig. 2). In this basin, surface water and ground water flow southward for about 20 miles (mi) before merging into Florida Bay via a number of small creeks and channels. The slough covers more than 158 square miles $\left(\mathrm{mi}^{2}\right)$ and extends about $21 \mathrm{mi}$ from its upstream end north of Frog Pond to the coastal mangroves along central Florida Bay (fig. 1). The Main Park Road partially encircles the study area to the north and west; the $\mathrm{C}-111$ canal is the easternmost boundary, and Florida Bay is the southernmost boundary (fig. 1). The northern portion of the slough is freshwater marsh dominated by rush and cypress heads; saltwater influence is apparent by the transition to sawgrass and mangroves on the southern part of the slough.

\section{Precipitation}

Precipitation data from the National Oceanic and Atmospheric Administration station at the Royal Palm Visitor Center, located within the basin, was utilized in this study (fig. 3). The bimodal wet season, which is characteristic of south Florida, has intense rainfall
Figure 3. Monthly rainfall and 30-year normal monthly rainfall for the National Oceanic and Atmospheric Administration station at the Royal Palm Visitor Center, Everglades National Park, Florida.

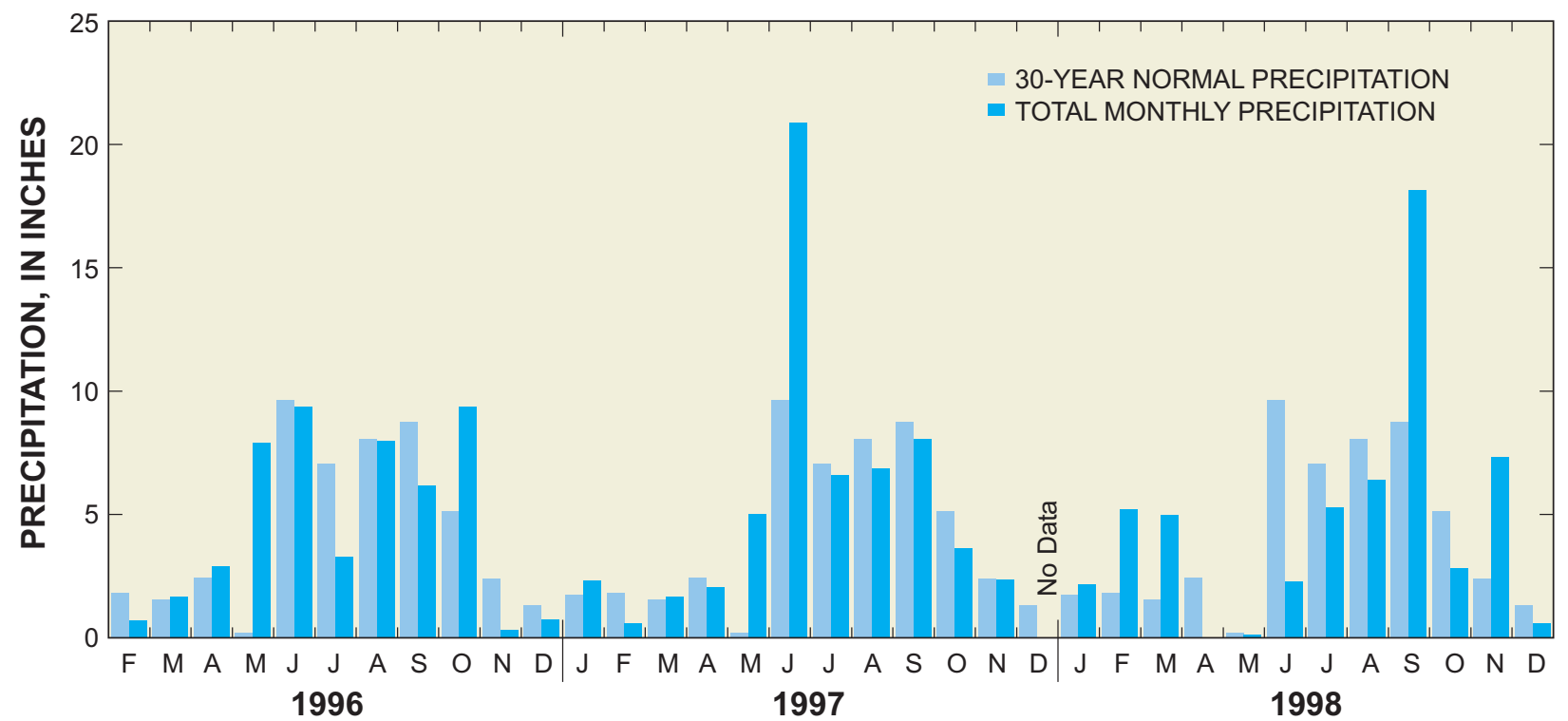


Table 1. Timetable of data-collection trips

[Dark shading represents the dates of data collection]

\begin{tabular}{|c|c|c|c|c|c|c|c|c|c|c|c|c|c|c|c|c|}
\hline & \multicolumn{12}{|c|}{1997} & \multicolumn{4}{|c|}{1998} \\
\hline & $7 / 29$ & $7 / 30$ & $7 / 31$ & 9/22 & $9 / 23$ & $9 / 24$ & $9 / 25$ & $9 / 26$ & $11 / 17$ & $11 / 18$ & $11 / 19$ & $11 / 20$ & $7 / 20$ & $7 / 21$ & $7 / 22$ & $7 / 23$ \\
\hline Transect 1 & & & & & & & & & & & & & & & & \\
\hline Transect 2 & & & & & & & & & & & & & & & & \\
\hline Transect 3 & & & & & & & & & & & & & & & & \\
\hline Transect 4 & & & & & & & & & & & & & & & & \\
\hline Centerline of slough & & & & & & & & & & & & & & & & \\
\hline C-111 outflow area & & & & & & & & & & & & & & & & \\
\hline L-31W & & & & & & & & & & & & & & & & \\
\hline Taylor Slough bridge & & & & & & & & & & & & & & & & \\
\hline Park road culverts & & & & & & & & & & & & & & & & \\
\hline C-111 culverts & & & & & & & & & & & & & & & & \\
\hline
\end{tabular}

during June, followed by a period of minor precipitation events until the onset of greater rainfall in late August or early September (Van Lent, 1993; McPherson and Halley, 1996). The 1997 calendar year was a particularly wet year, most likely the result of El Niño influenced weather patterns. June precipitation peaked at 20.90 inches (in.), more than twice the average of 9.64 in. (National Oceanic and Atmospheric Administration, 1996-98).

\section{DATA COLLECTION}

Four intensive data-collection trips into the Taylor Slough Basin were conducted during July, September, and November 1997, and July 1998 (table 1). These trips coincided with precipitation events that would produce sufficient water levels for airboat access (fig. 4), and covered a wide spectrum of water levels and flow conditions with which to conduct analyses. Data collected in this study have been

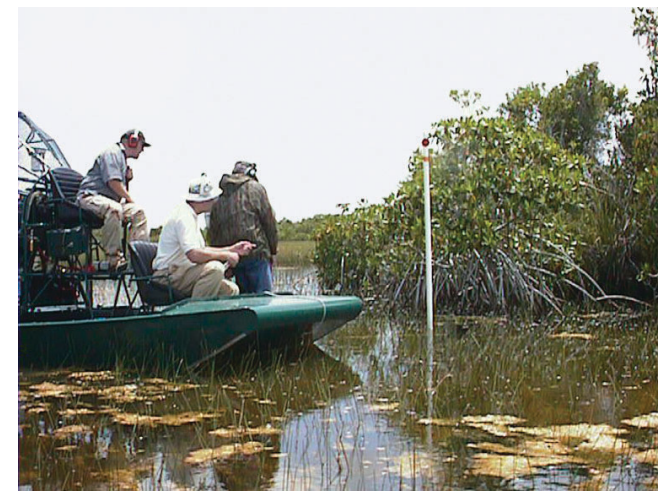

Figure 4. Airboat access to Taylor Slough. used to calibrate and verify a hydrodynamic model of the interconnected wetland and tidal ecosystem and to provide baseline data for evaluating processes such as evapotranspiration, flow resistance effects of vegetation, and groundwater/surface-water interactions. (Harvey, 1996; Jenter and Schaffranek, 1996; Schaffranek, 1996; Lee and Carter, 1997; Swain, 1999).

\section{Equipment}

The data-collection effort covered a wide variety of tasks and required various types of equipment. At sites where the use of acoustic instruments was impractical, vertical-axis current meters were used to measure water velocity. Vertical-axis current meters operate based on the proportionality between the velocity of the water and the resulting angular velocity of the meter's rotor. The number of revolutions the rotor completes during a measured interval of time is directly related to the water velocity at that point. Additionally, multiplying the water velocity by the cross sectional area of the stream produces an estimate of discharge. 
Figure 5. Signal patterns of an Acoustic Doppler Velocity meter and Acoustic Doppler Current Profiler.

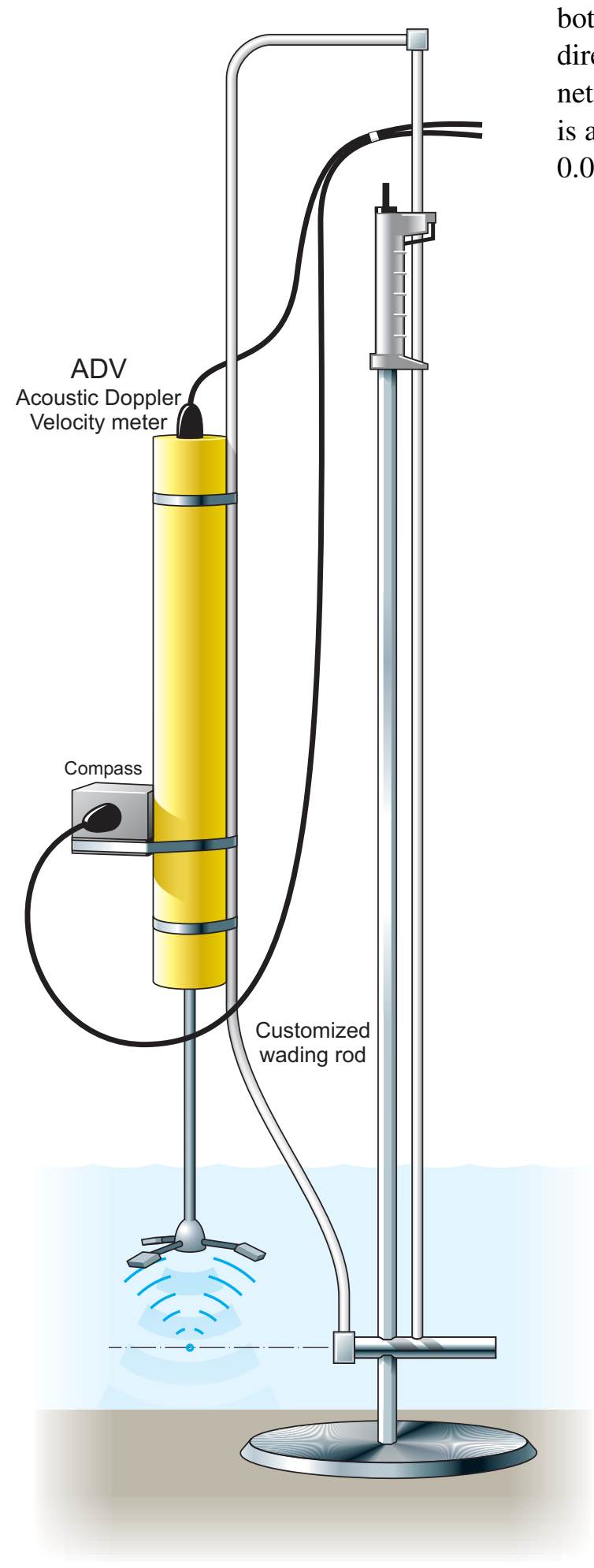

Acoustic instruments, called Acoustic Doppler Velocity-meters (ADVs) and Acoustic Doppler Current Profilers (ADCPs), use the Doppler shift principle by transmitting sound at a fixed frequency and recording the frequency-shifted echoes returning from particles in the water (Simpson and Oltman, 1993; Gordon, 1996; SonTek, 1996). By measuring acoustic travel time (fig. 5), these instruments are often capable of detecting the distance to a solid boundary, such as a channel bottom. The compass-equipped ADV records the velocity in three directional components: X, Y, and Z, which are translated into magnetic east, magnetic north, and up. The wading-rod-mounted ADV is a point velocity meter capable of measuring velocities as low as 0.0033 feet per second ( $\mathrm{ft} / \mathrm{s})$ in depths as shallow as 0.33 foot $(\mathrm{ft})$.

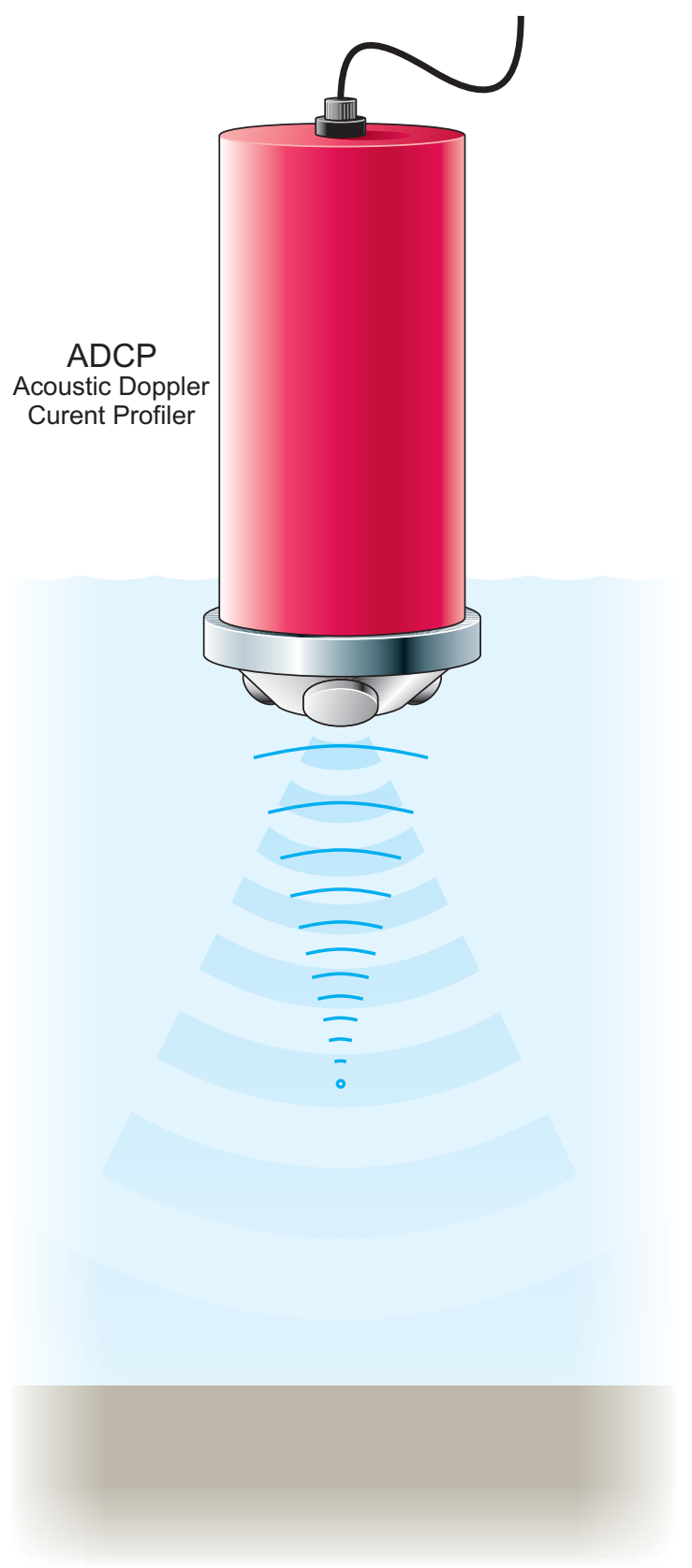




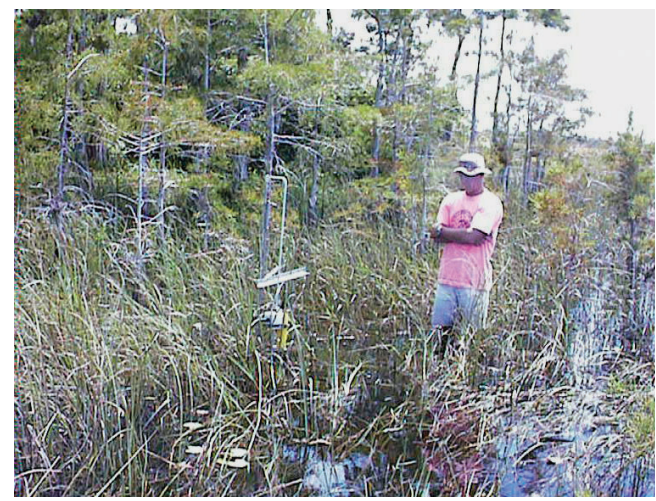

Figure 6. Typical Acoustic Doppler Velocity meter mounted on a specially designed wading rod.
The sample volume centroid is approximately $0.16 \mathrm{ft}$ from the probe tip. The vessel-mounted ADCP measures velocity throughout the water-column and computes total discharge as the boat moves across the cross section. The ADCP accurately measures flows as slow as $0.4 \mathrm{ft} / \mathrm{s}$ in depths as shallow as $3.3 \mathrm{ft}$ (USGS, 1997; RD Instruments, undated).

Customized wading-rods were designed for ADV velocity-profile measurements. A top-setting rod was used because of the convenience in setting the meter at the proper depth. The top-setting wading-rod has a $1 / 2$-inch hexagonal main rod for measuring depth and an adapted $3 / 8$-inch diameter round rod for setting the position of the ADV, accounting for the sample volume offset from the probe tip. Typically, a wading-rod base measures $3^{1 / 4}$ in. in diameter. The specially designed wading-rod base diameter is $1 \mathrm{ft}$. The larger base distributes the rod and meter weight over a greater area and minimizes compaction of the soft litter layer on the slough bottom. The base plate rests on the litter layer, and the depth of water is read on the graduated main rod.

Water-quality meters (collocated with all velocity profiles) collected data at middepth and measured the temperature, specific conductance, salinity, dissolved oxygen, and $\mathrm{pH}$. Measured temperature and salinity values were used in computation of water velocity because both parameters affect the speed of sound in water. All water-quality meters were calibrated at the beginning of each day.

Global Positioning System (GPS) instrumentation established horizontal sampling locations in North American Datum of 1983 (NAD83) coordinates. Field notes included the latitude and longitude coordinates, GPS drift, and description of distinctive features, (nearby staff gages and cypress heads). These coordinates were converted to Universal Transverse Mercator (UTM) coordinates (NAD83, Zone 17) for reporting and model input purposes.

After positioning the ADV for a velocity measurement with minimum disturbance to the surrounding vegetation and flow field, the hydrographer retreated from the probe and the presumed flow path (fig. 6). About 2 minutes was allowed for the sample area to return to equilibrium before starting a velocity measurement. Measurement bursts lasted 120 seconds, at a 10 hertz sampling rate, and produced time-series measurements of 1200 points at the appropriate depths in the water column.

\section{Description of Measurement Site Network}

The data-collection network was established for the purpose of quantifying boundary and internal flows for the Taylor Slough Basin along five internal transects in the basin and through culverts across the Main Park Road. The internal transects data were used to determine surface-flow magnitude and direction through the basin. The Main Park Road provided a "natural" boundary to the study area. 


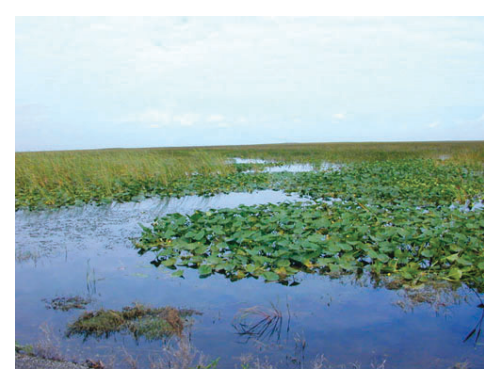

Inflows across this boundary were measured concurrently with the internal transects, utilizing vertical-axis current meters and ADCPs. Two concurrent South Florida Ecosystem projects, the Florida Bay and Canal Wetland Flow/Transport Interaction projects, provided tidal creek flow and C-111 canal overbank and outflow data along the southern and eastern boundaries of the study area (Patino, undated; Schaffranek, undated).

Measurement sites were restricted to areas along established airboat trails (fig. 1). Initially, internal flows were measured across three transect lines (T1, T2, and T3) bisecting the Taylor Slough Basin from east to west as well as a transect along the centerline axis of the slough. In November 1997, a fourth transect (T4) was added to the data-collection effort, connecting transects $\mathrm{T} 2$ and T3 along a north-south airboat trail. Three-dimensional velocity measurements were conducted at the transect sites utilizing ADVs, which provided the required levels of accuracy as well as rapid collection of multiple time series of flow data at these remote sites. Water depth, water-quality parameters, litter-layer thickness, weather conditions, site description, site location, bottom conditions, and vegetative cover were recorded concurrently with ADV measurements. Individual velocity sampling sites were chosen to be representative of the vegetation type and density as well as water depth in the surrounding area.

For water depths less than a foot, the velocity measured at 60 percent of the depth from the water surface was used as the mean velocity in the vertical water column. The three-point method (multiple measurements at 20,60, and 80 percent of the depth from the water surface) were used when water depths were $1 \mathrm{ft}$ or greater. Wind influence, non-uniform bottom, vegetative resistance to flow, variable flow area, and shallow water depths added to the complexity of the velocity profile. Therefore, the three observations were averaged arithmetically to determine the mean water-column velocity (Rantz and others, 1982). On occasion, more points were measured in the water column and the depth-weighted mean of the observations was used as the mean water-column velocity.

Flow through 128 culverts across the Main Park Road from the ENP entrance to Nine Mile Pond, fig. 1, was measured using verticalaxis Pygmy current meters. The Pygmy current meters were used for water depths of 0.3 to $2.5 \mathrm{ft}$ and vertical-axis Price AA current meters were used for depths of $2.5 \mathrm{ft}$ and greater (Rantz and others, 1982). Flow under Taylor Slough and L-31W bridges was measured with vertical-axis Price AA current meters. Additionally, an ADCP measured flow losses from the L-31W canal, between structure S175 and its terminus (about 3.5 mi south of S175) where all flow becomes sheetflow through the wetlands. 


\section{Geometric Properties of Transects}

The data-collection effort intended to have transects perpendicular to the slough axis. However, to minimize environmental damage, measurements were confined to locations along established airboat trails (fig. 1). These trails follow the slough's natural landscape features and are not always perpendicular to the slough axis. Transect T1 is fairly straight with the exception of a detour around cypress heads near the slough's center. Transect T2 is the most noncollinear transect, owing to numerous tree islands and firebreaks. Transect T3's bowed shape results from the natural meander of creeks through the dense mangrove forest near the centerline of the slough. However, the mangroves give way to open water and sparse sawgrass on the western and eastern sections of the transect. Transect T4 follows a winding airboat trail south from transect $\mathrm{T} 2$ to transect $\mathrm{T} 3$.

\section{Data Analysis}

ADV data were postprocessed utilizing software from the equipment manufacturer. Postprocessed files include the control file (input information required to operate the ADV equipment), velocity (components in the magnetic east, magnetic north, and up directions), correlation (data quality for each of the three acoustic receivers), and signal-to-noise ratio (signal strength for each of the three acoustic receivers).

An automated spreadsheet incorporated post-processed files for further processing to determine the average east-west and north-south velocity components at each measurement depth. The velocity components were adjusted to account for declination, the difference between true north and magnetic north. These data were used to calculate the time-averaged velocity magnitude and direction at each measurement depth as well as the mean water-column velocity, with respect to true north, for each measurement site.

A data base was developed to facilitate information and data transfer of all collected data to South Florida Ecosystem Program researchers. The data base contains all field note data as well as processed velocity data. The data-base "key," a unique identifier for each data-base record, is based on the site location and date of measurement. For example, W01T20997 represents the measurement at site W01 on transect T2 in September 1997. Site locations are available in both NAD83 latitude and longitude coordinates as well as UTM coordinates. An output data format that emulates the actual field notes is shown in figure 7. The data base and spreadsheets can be accessed at http://sofia.usgs.gov/projects/flow_velocity/ on the World Wide Web.

As a quality-assurance procedure, spot checks were conducted as well as complete duplication of the data analysis process for random sites. Utilizing a spreadsheet template minimized data input and processing error. Additionally, examination of the control file, filtered data summaries, profile computations, histograms, and graphs helped detect data errors. 


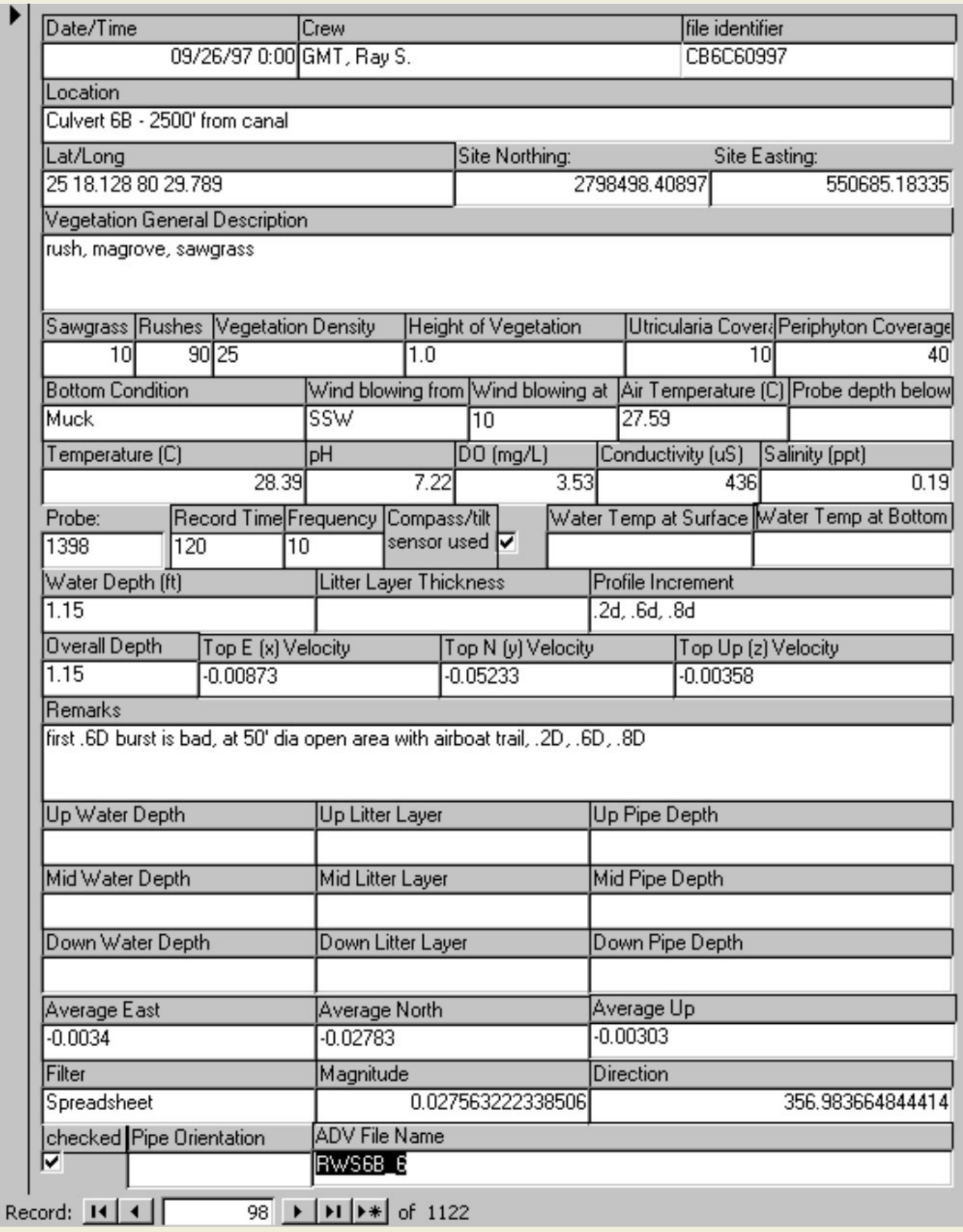

Figure 7. Electronic format of field notes and processed velocity data available as output from data base. 


\section{RESULTS}

The primary products of this effort are data files of flow and velocity in the Taylor Slough Basin representing different seasonal conditions. This section describes the seasonal variability of the data as well as its availability and format options via the World Wide Web. Seasonal variability of net water flow into the system and surface flow within the basin are presented. This section also describes the data base, which summarizes all of the collected hydrologic data, spreadsheets, and a text version of the data base.

\section{Seasonal Variability of Velocity and Discharge}

Taylor Slough interface with Florida Bay
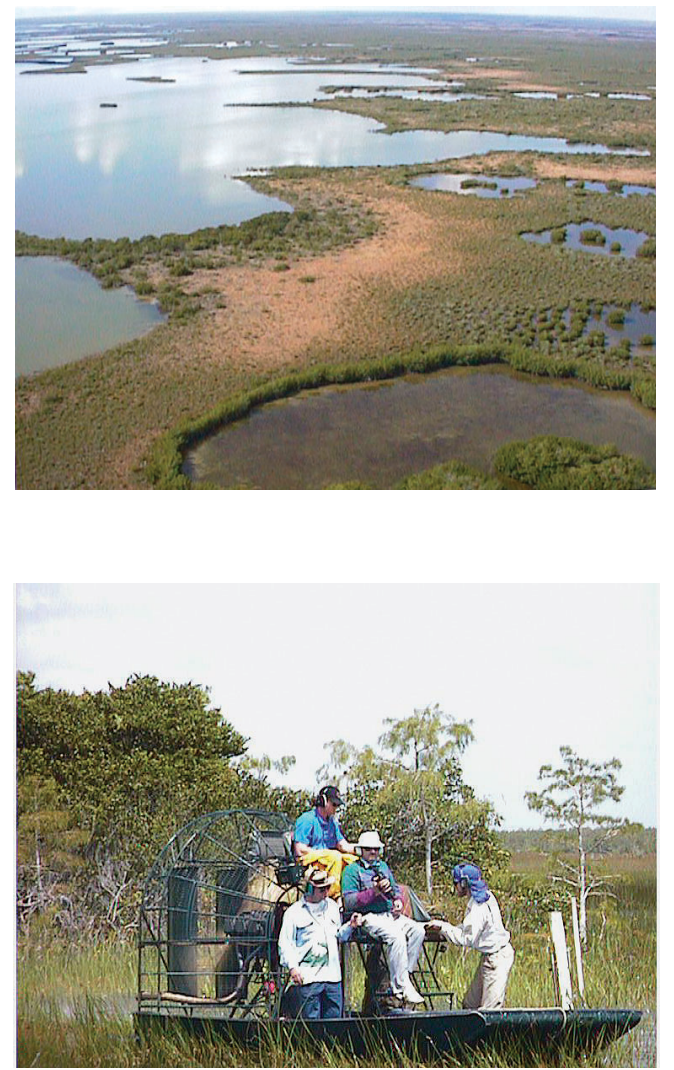

USGS and National Park Service employees observing water levels
Flows across the Main Park Road were measured for each datacollection trip, and were grouped into five categories based on hydrologic divides and manmade barriers: (1) flow in the L-31W canal; (2) the sum of flows from the park entrance to the Royal Palm Road, including flow under the Taylor Slough bridge; (3) the sum of flows from Royal Palm Road to the Pa-hay-okee Overlook; (4) the sum of flows from the Pa-hay-okee Overlook to the Mahogany Hammock; and (5) the sum of flows from the Mahogany Hammock to the Nine Mile Pond picnic area (fig. 1).

During the July 1997 trip, there was a total inflow of 144 cubic feet per second $\left(\mathrm{ft}^{3} / \mathrm{s}\right)$ from the L-31W canal and the Main Park Road culverts, extending from the park entrance to Royal Palm Road (fig. 8). Culvert flows were not measured west of the Royal Palm Road. For the September 1997 data-collection trip, an inflow of $303 \mathrm{ft}^{3} / \mathrm{s}$ was measured from the L-31W canal to the Pa-hay-okee Overlook. A net outflow of $125 \mathrm{ft}^{3} / \mathrm{s}$ from the basin was measured between the Pa-hay-okee Overlook and the Nine Mile Pond picnic area (fig. 9). On November 17, 1997, an inflow of $31 \mathrm{ft}^{3} / \mathrm{s}$ was measured from the L-31W canal to the Pa-hay-okee Overlook. A net outflow of $33 \mathrm{ft}^{3} / \mathrm{s}$ from the basin was measured between the Pa-hay-okee Overlook and the Nine Mile Pond picnic area (fig. 10). For the July 1998 datacollection trip, an inflow of $122 \mathrm{ft}^{3} / \mathrm{s}$ was measured from the park entrance to the Pa-hay-okee Overlook. A net outflow of $119 \mathrm{ft}^{3} / \mathrm{s}$ from the basin was measured between the Pa-hay-okee Overlook and Nine Mile Pond picnic area (fig. 11).

The measured velocity directions were similar for the July 1997 and September 1997 periods (figs. 8 and 9). However, speeds were significantly greater for the high-water period (September 1997), with speeds typically five times greater than those measured in July 1997. September 1997's net inflow was $178 \mathrm{ft}^{3} / \mathrm{s}$ as contrasted with a net outflow of $2 \mathrm{ft}^{3} / \mathrm{s}$ in November of 1997 . The L-31W to Royal Palm Road inflow in September 1997 was about double that of July 1997. Speeds decreased significantly for the low-water measurement in November 1997 (fig. 10), less than half the magnitude of those measured in July 1997 (fig. 8). 


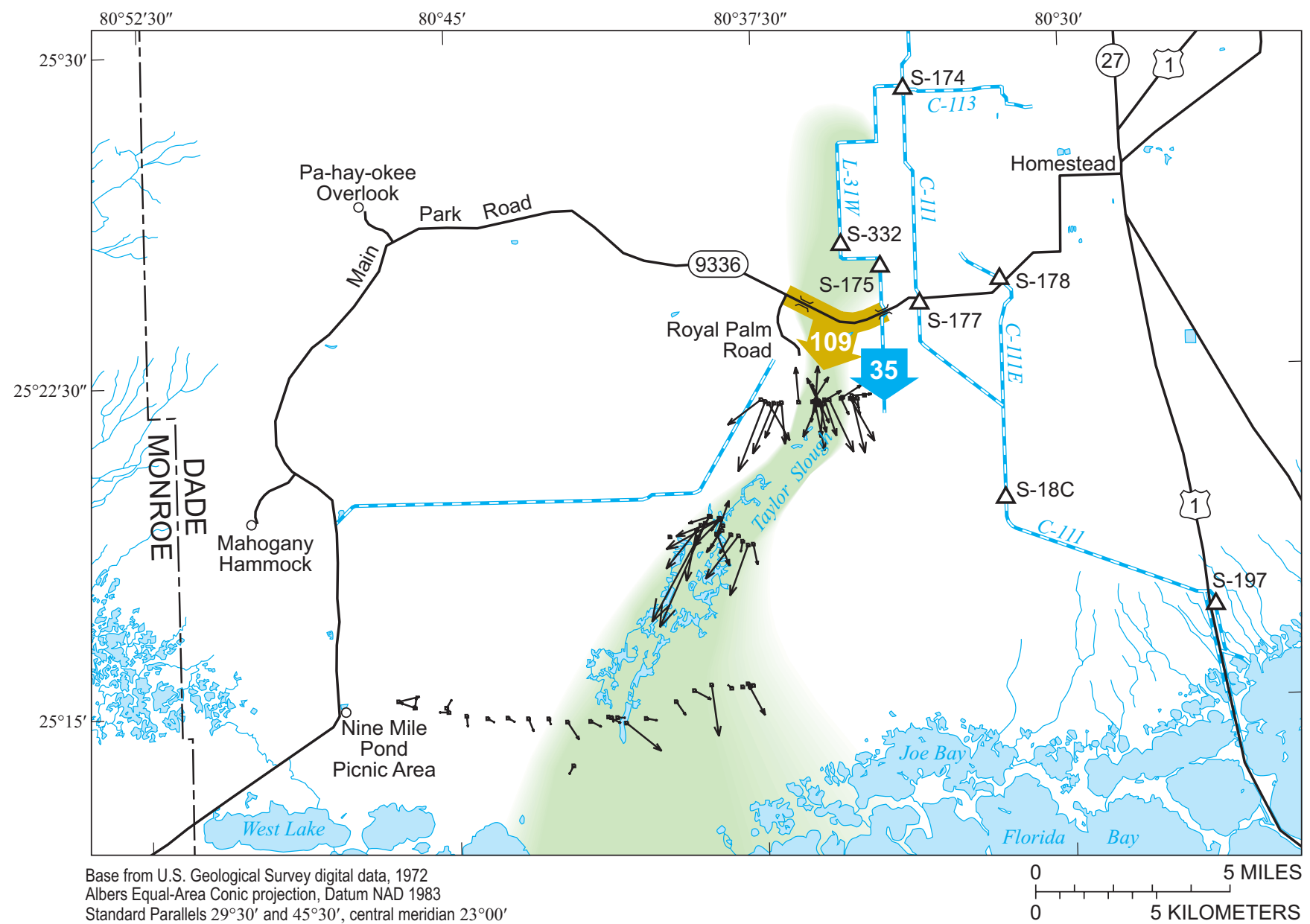

EXPLANATION

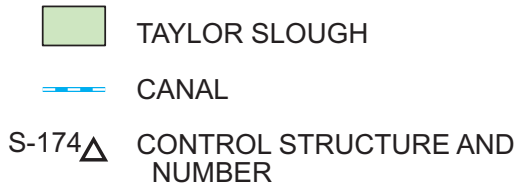

$\longleftrightarrow$ VELOCITY FLOW VECTOR-Length is relative to
velocity magnitude. Example shown represents velocity magnitude. Example show

35 NET FLOW-Sum of culvert and bridge flows, in cubic feet per second, under the Main Park Road. Flow in L-31W canal represents flow under bridge

Figure 8. Flow measurements for July 1997.

Although water levels were similar for the July 1997 and July 1998 measurements, July 1998 flow patterns differed significantly from all previous data-collection trips (fig. 11). These flow differences could be due to the effect of a steady, strong wind from the south over open water. Because flow velocities are extremely low in Taylor Slough, water movement may be susceptible to winds that reverse the general flow direction. Wind direction and speed data are recorded at http://sofia.usgs.gov/metadata/sflwww/germanwl.html.

\section{Web-Based Products}

Data collected for this effort are available in downloadable formats and can be accessed at http://sofia.usgs.gov/projects/ flow_velocity/. A data base summarizing the processed hydrologic 


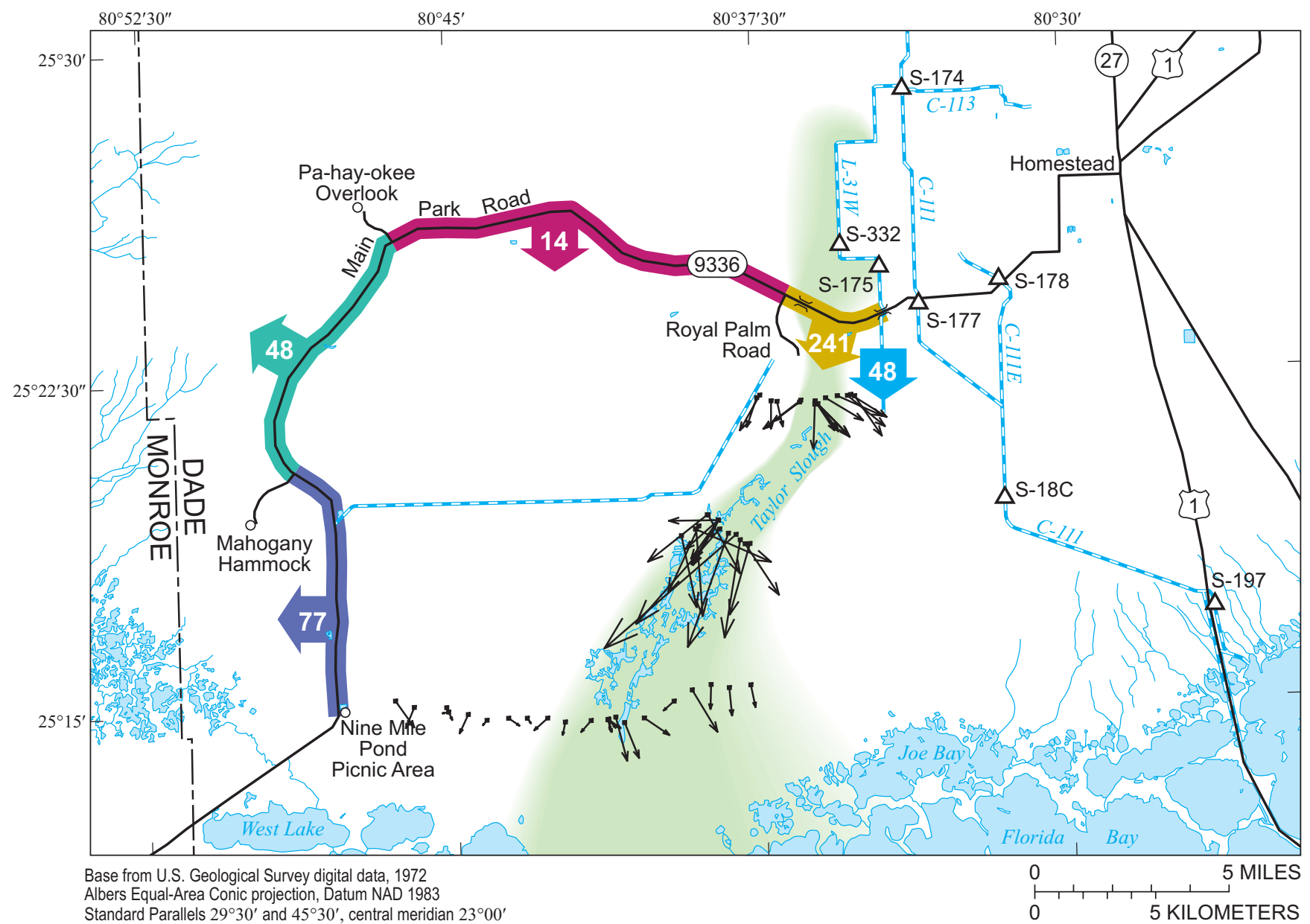

EXPLANATION

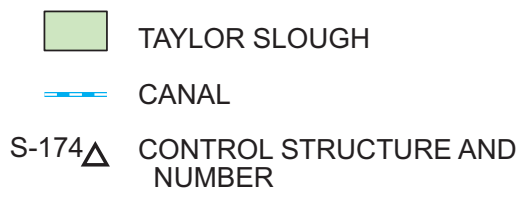
$\longleftrightarrow$ VELOCITY FLOW VECTOR-Length is relative to velocity magnitude. Example shown represents a velocity of 0.04 feet per second

48 NET FLOW-Sum of culvert and bridge flows, in cubic feet per second, under the Main Park Road. Flow in L-31W canal represents flow under bridge

Figure 9. Flow measurements for September 1997.

data includes information for all measurement sites, including location, site description, water velocity, water depth, and measurement depth. The data base can be viewed as an electronic format of field notes (fig. 7) or as a table. Additionally, a text version of the data-base table is available. Spreadsheets, used to postprocess raw velocity data, are available for downloading and are organized by transect, station ID, and date of data collection.

\section{SUMMARY}

Hydrologic data were collected in the Taylor Slough Basin, representing a wide spectrum of water levels and associated flow conditions. These data were used for calibrating and verifying a hydrodynamic model and evaluating evapotranspiration, resistance 


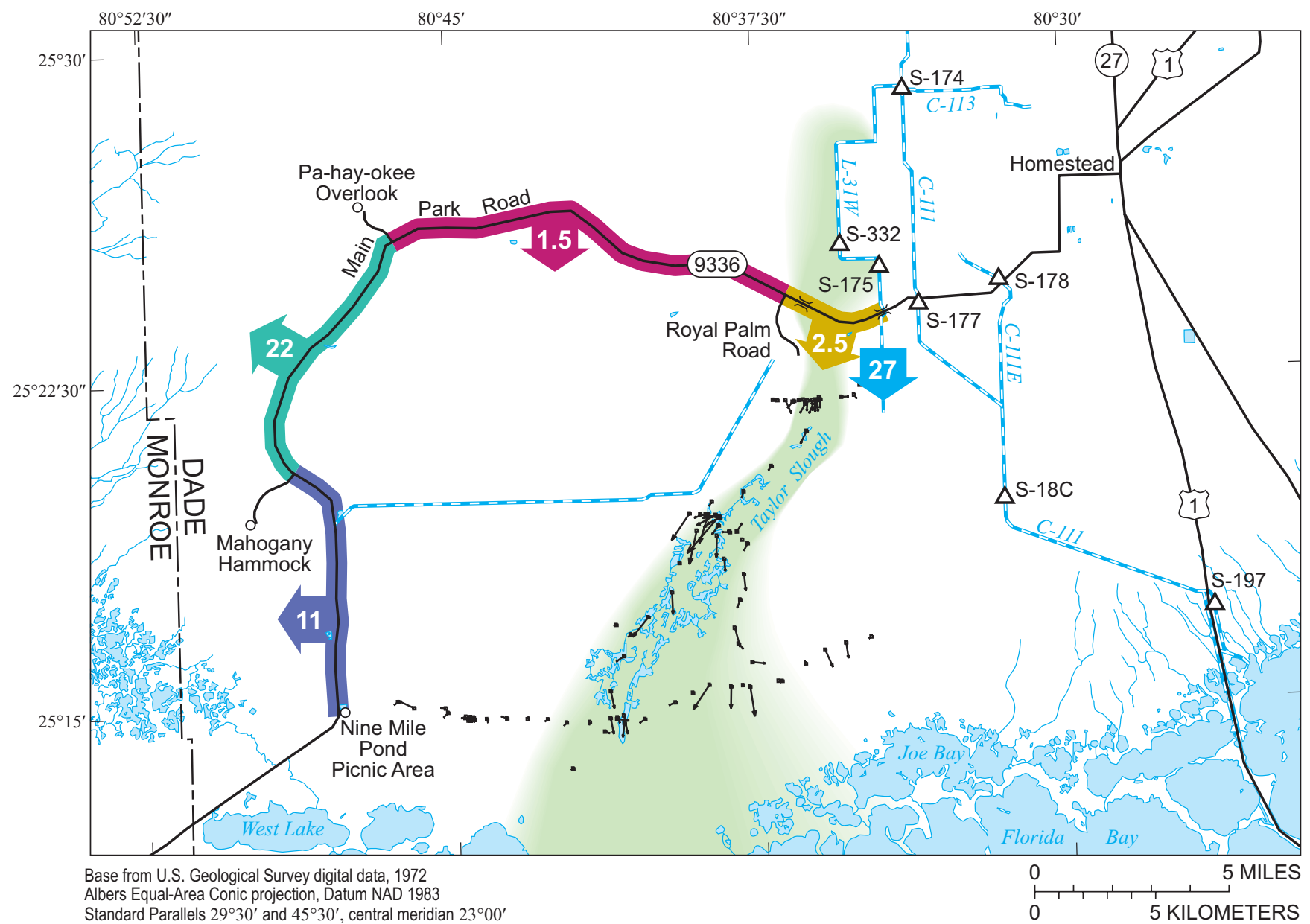

EXPLANATION

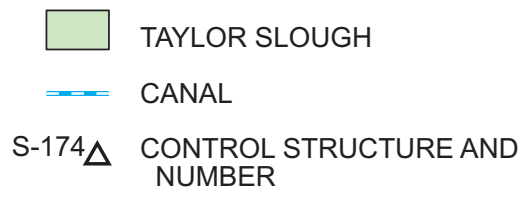
$\longrightarrow$ VELOCITY FLOW VECTOR-Length is relative to velocity magnitude. Example shown represents a velocity of 0.04 feet per second

27 NET FLOW-Sum of culvert and bridge flows, in cubic feet per second, under the Main Park Road. Flow in L-31W canal represents flow under bridge

Figure 10. Flow measurements for November 1997.

effects of vegetation, and ground-water/surface-water interactions. Flows across the study area's Main Park Road boundary provided net flow of water into the system and transect measurements provided flow-field data within the Taylor Slough Basin. The high-water event in September 1997 produced the highest velocity flow magnitudes. The low-water event in November 1997 produced the lowest velocity flow magnitudes and net outflow from the basin. The July 1998 data had lower than expected velocity flow magnitudes and, in some cases, strong winds may have caused reversal of flow direction.

Data collected during this study is available electronically for all measurement sites through the World Wide Web. The downloadable data base and spreadsheets, can be accessed at http://sofia.usgs.gov/ projects/flow_velocity/. 


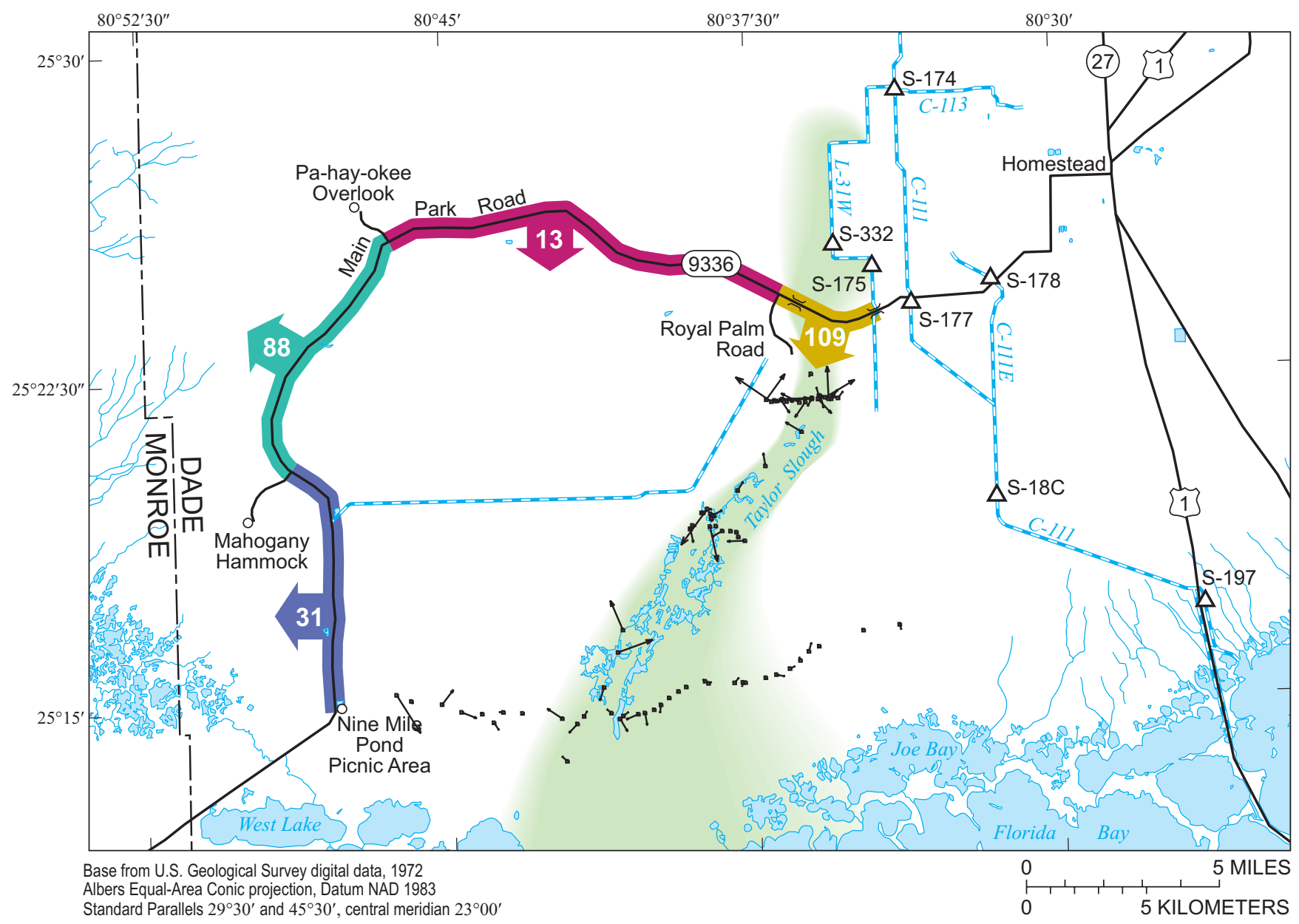

EXPLANATION

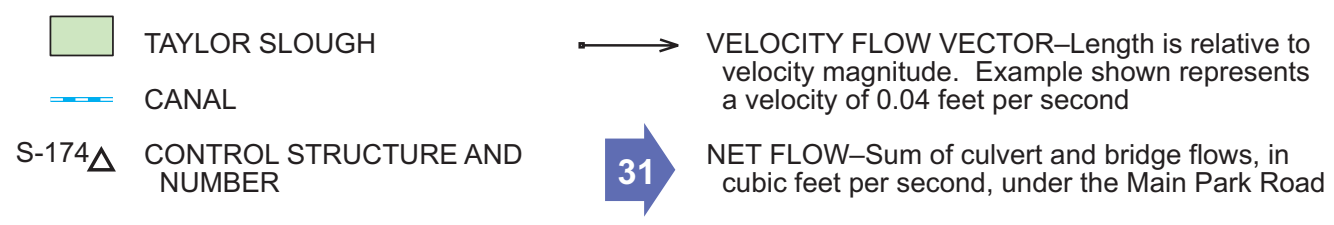

Figure 11. Flow measurements for July 1998.

\section{REFERENCES}

Bales, J.D., Fulford, J.M., and Swain, E.D., 1997, Review of selected features of the natural system model, and suggestions for applications in south Florida: U.S.

Geological Survey Water-Resources Investigations Report 97-4039, 42 p.

German, E.R., undated, Everglades ET measurement and modeling, U.S. Geological Survey South Florida Information Access Webpage, http://sofia.usgs.gov/metadata/ sflwww/germanwl.html, updated regularly, variously paged.

Gordon, R.L., 1996, Acoustic Doppler Current Profiler, Principles of operation, A practical primer Broadband ADCPs (2d ed.): San Diego, Calif., RD Instruments, $51 \mathrm{p}$.

Harvey, J.W., 1996, Vertical exchange of ground water and surface water in the Florida Everglades: U.S. Geological Survey Fact-Sheet 169-96, 4 p.

Jenter, H.L., and Schaffranek, R.W., 1996, Vegetation affects water movement in the Florida Everglades: U.S. Geological Survey Fact-Sheet 147-96, 4 p.

Lee, J.K., and Carter, Virginia, 1997, Vegetative resistance to flow in the Everglades: U.S. Geological Survey Open-File Report 97-385, 2 p. 
McPherson, B.F., Gerould, Sarah, and Higer, A.L., 1999, USGS science for restoration of south Florida: The South Florida Ecosystem Program: U.S. Geological Survey Fact Sheet 061-99, 4 p.

McPherson, B.F., and Halley, Robert, 1996, The south Florida environment-A region under stress: National Water-Quality Assessment Program: U.S. Geological Survey Circular 1134, $61 \mathrm{p}$.

Meyer, F.W., and Hull, J.E., 1969, Hydrologic conditions in the Canal 111 area: February 14-June 27, 1968, U.S. Geological Survey Provisional Data, $44 \mathrm{p}$.

National Oceanic and Atmospheric Administration, 1996, Climatological data, Annual summary, Florida, 1996, U.S. Department of Commerce, v. 100, no. 13, ISSN-0145-0484.

1997, Climatological data, Annual summary, Florida, 1997, U.S. Department of Commerce, v. 101, no. 13, ISSN-0145-0484.

1998, Climatological data, Annual summary, Florida, 1998, U.S. Department of Commerce, v. 102, no. 13, ISSN-0145-0484.

Patino, Eduardo, undated, Freshwater flows into northeastern Florida Bay, U.S. Geological Survey South Florida Information Access Webpage, http://sofia.usgs.gov/projects/freshwtr_ flow/, updated regularly, variously paged.

Rantz, S.E., and others, 1982, Measurement and computation of streamflow: Volume 1. Measurement of stage and discharge: U.S. Geological Survey Water-Supply Paper 2175, 284 p.

RD Instruments, undated, Acoustic Doppler Current Profilers-River application note, ADCP water modes: San Diego, Calif., 1 p.

Schaffranek, R.W., 1996, Coupling models for canal and wetland interactions in the south Florida ecosystem: U.S. Geological Survey Fact-Sheet 139-96, 6 p.

\section{U.S. DEPARTMENT OF THE INTERIOR GALE A. NORTON, Secretary}

\section{U.S. GEOLOGICAL SURVEY \\ Charles G. Groat, Director}

For additional information write to:

District Chief

U.S. Geological Survey

Suite 3015

227 N. Bronough Street

Tallahassee, FL 32301

Copies of this report can be purchased from:

U.S. Geological Survey

Branch of Information Services

Box 25286

Denver, CO 80225

(phone) 888-ASK-USGS

Any use of trade, product, or firm names in this publication is for descriptive purposes only and does not imply endorsement by the U.S. Geological Survey

Additional information about water resources in Florida is available on the World Wide Web at http://fl.water.usgs.gov
Schaffranek, R.W., undated, Canal and wetland flow/transport interaction, U.S. Geological Survey South Florida Information Access Webpage, http://sofia.usgs.gov/projects/coupling_ $m d l s$, updated regularly, variously paged.

Simpson, M.R., and Oltmann, R.N., 1993, Discharge-measurement system using an Acoustic Doppler Current Profiler with applications to large rivers and estuaries: U.S. Geological Survey Water-Supply Paper 2395, 32 p.

SonTek, 1996, Acoustic Doppler velocimeter principles of operation, SonTek Technical News, 15 p.

Swain, E.D., 1999, Numerical representation of dynamic flow and transport at the Everglades/Florida Bay interface: Proceedings of the $3^{\text {rd }}$ International Symposium on Ecohydraulics, July 13-16, 1999, Salt Lake City, Utah, 9 p.

Tsihrintzis, V.A., Sikkema, D., Levinson, M., and Oliveros, J.L., 1996, Discharge measurement and prediction in wetlands: North American Water and Environment Congress '96, ASCE, June 22-28, Anaheim, Calif., 6 p.

U.S. Geological Survey, 1997, National coordination and support for Acoustic Doppler Current Profiler activities: Office of Surface Water Technical Memorandum No. 97.02, 2 p.

Van Lent, T.J., 1993, Analysis of the historical Taylor Slough rainfall/flow relationship: University of Virginia, Environmental Sciences Department, $21 \mathrm{p}$.

Van Lent, T.J., Johnson, Robert, and Fennema, Robert, 1993, Water management in Taylor Slough and effects on Florida Bay: South Florida Research Center, Everglades National Park, National Park Service, 88 p.

\section{ACKNOWLEDGMENTS}

\section{U.S. Geological Survey:}

$\begin{array}{ll}\text { Gordon Anderson } & \text { Lavetra Sloan } \\ \text { Tim Boozer } & \text { Rick Solis } \\ \text { Virginia Carter } & \text { Mark Stephens } \\ \text { Darryl Chinn } & \text { David Stewart } \\ \text { Elizabeth Debiak } & \text { Eric Swain } \\ \text { Greg Donley } & \text { Jim Tomberlin } \\ \text { James "Blu" Dubuisson } & \text { Twila Wilson }\end{array}$

Marvin Franklin

Alex Gallagher

Patricia Gammon

Linda Geiger

Don Goin

Judson Harvey

Gregory Hendricks

Heather Henkel

Harry Jenter

Kenny Kalan

Jon Lee

Paul Meadows

Bob Mooney

Eduardo Patino

Kathleen Pegram

John Pittman

Justin Reel

Leonardo Robinson

Henry Ruhl

Nancy Rybicki

Ray Schaffranek
National Park Service:

Allette Karavitis

Bob Zepp

Volunteers:

Thomas "Tony" Brock

Darryl Daniels

Dave Harvey

Mitchell House

Lance McLellan

Gator McLellan

Eddie Rewis

Richard Smith

James "Red" Wood

Photography:

Heather Henkel

Eric Swain

Gina Tillis 